\title{
シンポジウム記録 若手研究者による中国・四国地方の水産研究とこれから
}

\section{6. 瀬戸内海燧灘におけるカタクチイワシシラス の不漁要因調査}

藤田辰徳

香川県水産試験場

6. Factors survey of poor catch about larval Japanese anchovy Engraulis japonicus in Hiuchi-nada, central Seto Inland Sea

TATSUNORI FUJITA

Kagawa Prefectural Fisheries Experimental Station, Takamatsu, Kagawa 761-0111, Japan

カタクチイワシは瀬戸内海の重要な漁業資源であり, 香川県では，燧灘において瀬戸内海機船船びき網漁業に よりその多くが漁獲される。当県では, 1980 年代から 調査海域の卵密度に基づいて仔魚の発生量を推定し，シ ラス漁況予報を作成してきた。しかし，近年では卵密度 が高いにも拘わらずシラスの漁獲量が少ない傾向が続い て抢り，シラスの発生予測が難しくなっている。そこ で，シラスの加入低迷の原因を究明することを目的とし て, 本研究では, まず定点調査や漁獲量などに基づい て, カタクチイワシ卵密度と発生旬ごとのカタクチイワ シ仔稚魚の漁獲尾数の関係を調べた。次に, 2015 年2017 年には, シラスの加入量が多い 5 月-6 月発生群の 仔魚密度と, 水深 $10 \mathrm{~m}$ の $100 \mu \mathrm{m}$ 以下カイアシ類ノー プリウス幼生の出現状沉を調査し, 拱䬲開始期仔魚の生 残状況について考察した。

当該海域の 5 月頃に該当する, カタクチイワシの産 卵開始から盛期に至る表面水温 ${ }^{1)} 16-21.7^{\circ} \mathrm{C}$ に打ける烼 灘東部海域のカタクチイワシ卵密度と, 同時期に発生し
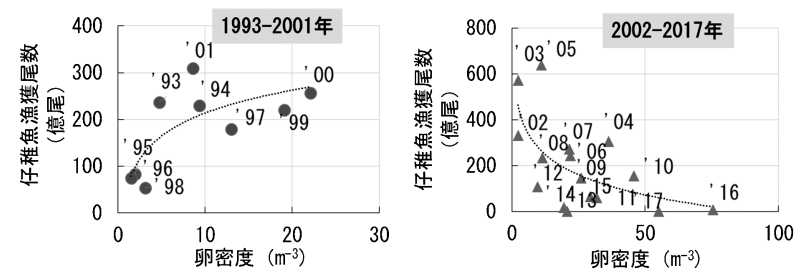

図 1 産卵開始期のカタクチイワシ卵密度と仔稚魚漁獲 尾数の関係

たと考えられるカタクチイワシ仔稚魚の漁獲尾数の関係 には，年代で明確な違いが認められた。1993 年-2001 年では卵密度と漁獲尾数の関係に正の相関が認められた が， 2002 年-2017 年では卵密度が高くなるほど, 漁獲 尾数が少なくなることが示された（図 1$)$ 。このことか ら, 近年では, 産卵開始期にあたる 5 月発生群が漁獲 加入していない可能性が示唆された。

仔魚密度調查では, 子化仔魚は 5 月から 6 月までの 間に多く採集されたが，体長 $9 \mathrm{~mm}$ 以上の仔魚は， 5 月 にはほとんど採集されなかったのに対して，6月以降の 一定の時期には比較的多く採集された。ノープリウス幼 生の密度は時期によって出現状況に違いが認められ，5 月は 6 月に比べて少なかった。以上の結果から，5月発 生群は, 近年では発育初期に死亡していることが示唆さ れ，摂䬣開始以降の䭒料環境の悪化がその一因ではない かと考えられた。今後も, 本海域に打けるシラスの加入 低迷の原因を多角的に究明していく予定である。

\section{文献}

1）河野悌昌, 銭谷 弘. 1980 2005 年の瀬戸内海における カタクチイワシの産卵量分布. 日本水産学会誌 2008; 74 (4): 636-644 